\title{
ECO-INNOVATIONS IN RURAL TERRITORIES: ORGANIZATIONAL DYNAMICS AND RESOURCE MOBILIZATION IN LOW DENSITY AREAS
}

\author{
Danielle Galliano, Amélie Gonçalves, Pierre Triboulet
}

De Boeck Supérieur | «Journal of Innovation Economics \& Management »

2017/0 Prépublication | pages art14I à art14XXVI

\section{Article disponible en ligne à l'adresse :}

http://www.cairn.info/revue-journal-of-innovation-economics-2017-0-page-art14I.htm

\section{Pour citer cet article :}

Danielle Galliano et al., « Eco-Innovations in Rural Territories: Organizational Dynamics and Resource Mobilization in Low Density Areas », Journal of Innovation Economics \& Management 2017/0 (Prépublication), p. art14I-art14XXVI.

Distribution électronique Cairn.info pour De Boeck Supérieur.

(c) De Boeck Supérieur. Tous droits réservés pour tous pays.

La reproduction ou représentation de cet article, notamment par photocopie, n'est autorisée que dans les limites des conditions générales d'utilisation du site ou, le cas échéant, des conditions générales de la licence souscrite par votre établissement. Toute autre reproduction ou représentation, en tout ou partie, sous quelque forme et de quelque manière que ce soit, est interdite sauf accord préalable et écrit de l'éditeur, en dehors des cas prévus par la législation en vigueur en France. Il est précisé que son stockage dans une base de données est également interdit. 


\title{
ECO-INNOVATIONS IN RURAL TERRITORIES: ORGANIZATIONAL DYNAMICS AND RESOURCE MOBILIZATION IN LOW DENSITY AREAS ${ }^{1}$
}

\author{
Danielle GALLIANO \\ UMR AGIR - INRA Toulouse, France \\ danielle.galliano@inra.fr \\ Amélie GONCALALES \\ UMR AGIR - INRA Toulouse, France \\ amelie.goncalves@inra.fr \\ Pierre TRIBOULET \\ UMR AGIR - INRA Toulouse, France \\ pierre.triboulet@inra.fr
}

\begin{abstract}
Rural areas are generally considered as less innovative because of the limited agglomeration of activities found within them. There has been little research on innovation in rural areas, whereas there are many environmental innovation projects in these areas. In this study we propose an analytical framework to examine the role of internal organizational factors and environmental factors (sectoral, spatial, and regulatory) that influence the development of eco-innovation projects. We tested this framework by using an original method: the Quantified Narrative Method, applied to five cases studies in French rural areas. Based on in-depth interviews, this method enabled the identification of external resources (nature, mode of acquisition, and location) used by the project. The results show the importance of personal networks - especially local professional networks - and leaders to strengthen the project's absorptive capacity (mobilization of specific local factors, development of related activities). While local resources remain crucial for these projects, remote resources are increasingly mobilized along the projects' path.
\end{abstract}

1. Acknowledgements: This study was carried out as part of the project "TASTE: Toward a Smart Rural Europe" (FP7 RURAGRI ERA-NET), and the French LABEX "SMS: Structuring social worlds" (ANR-11-LABX-0066). The authors would like to thank all the persons interviewed. They also thank Nathalie Chauvac for her work on the Qualisol case study. 
Keywords: Eco-Innovation, Rural, Trajectories, Organization, Environmental Factors, External Resources

JEL Codes: 031, R110, Q560

Rural areas are facing profound changes, particularly a continuing decline in the importance of agriculture to their economy, increases in environmental constraints, and a growing dependence with urban areas (Lennert, Robert, 2007). These changes question the processes of development in these regions (Torre, Wallet, 2015) and the dynamics of innovation supporting these processes. In spite of their vested interest in innovation, rural areas are generally considered to be inadequately innovative, in particular because of a lower degree of agglomeration of activities and knowledge (Audretsch, Feldman, 2004). However, recent publications cast doubt on this vision. They underline the ways in which new technologies in information and communication are profoundly modifying the links between activities, knowledge and space (Shearmur, Doloreux, 2016). These studies show that firms located in rural areas are often as innovative as similar firms located in urban or peri-urban areas (Magrini, Galliano, 2012). In addition, they point to the development of specific innovation projects in rural territories. These projects are often built on natural resources and agro-ecology, and have very different paths to those seen in mainstream agri-food systems (Doloreux et al., 2007; Levidow, 2015). They can also be considered as eco-innovative. Eco-innovation has been defined by the literature as a new or modified product, process, technique, or management system that avoids or reduces negative impacts on the environment (Horbach, 2008).

Our objective is to increase knowledge concerning the dynamics of innovation in rural areas. More specifically, we want to use empirical research methods to analyze the determining factors and mechanisms observed in the emergence and development of eco-innovation projects in these areas. We will identify the respective roles of internal organizational factors and environmental factors (sectoral, spatial, and regulatory) in an eco-innovation framework similar to that of Rennings (2000). The analysis of the eco-innovation process should also allow a better understanding of the coevolutionary path of the projects and their environment. In other words, our purpose is to analyze the impact of low economic activities density on coordination among actors and the way resources are mobilized in the innovation process.

Empirically, this article is based on an analysis of five eco-innovation projects. This analysis was undertaken to improve our understanding of the 
trajectories and processes involved in the development of eco-innovation. We applied a specific method to these cases: the Quantified Narratives Method (QNM, Grossetti, 2010; Grossetti et al., 2011). The QNM is relevant for an in-depth analysis of the projects' development processes, especially in terms of nature, mode of acquisition and location of the resources used during these processes.

The first section of this paper presents the theoretical framework based on a geographical approach to the economic literature on eco-innovation. The second presents the case studies and the QNM methodology. Results from our analysis of structure and dynamics in the five eco-innovation projects are described in the third section.

\section{THE DETERMINING FACTORS FOR ECO-INNOVATION}

Drawing on the work of Rennings (2000), the literature on eco-innovation and its determinants emphasizes the respective role of three groups of factors: organizational factors as they relate to supply (technology push), sectoral and market factors (demand pull), and regulatory (push/pull) factors affecting innovation processes (Horbach et al., 2012). This framework helps to bridge the differences between the economics of environment, which is centered on the analysis of regulatory effects on innovation, and the economics of innovation and technical change (Malerba, 2005). However, this literature pays little attention to the spatial dynamics of eco-innovation, in spite of the importance of these dynamics in the production of environmental externalities and their frequent linkages with local resources (Porter and Van Der Linde, 1995; Del Rio Gonzalez, 2009). Our goal in this section is to provide an appropriate framework for analyzing the respective influence of internal factors related to the organization and external factors, linked to the environment, by focusing on the ways in which modes of coordination and networks of actors influence the dynamic of eco-innovation projects in rural areas (Esparcia, 2014).

\section{Organizational Factors: Internal Resources and Absorptive Capacity to Eco-Innovate}

Existing research on innovation suggests that organization's characteristics have a critical impact on the ability to innovate. This is based on the hypothesis that each organization has a range of internal resources and a capacity to absorb external resources, and that these elements influence its propensity 
to innovate. This organizational design and its governance is particularly important to the dynamics and efficiency of eco-innovation projects.

As noted in the seminal work of Cohen and Levinthal (1990), the organizational structure, innovative profile and absorptive capacity are thus recognized as fundamental to the process of innovation. The absorptive capacity refers to the ability of an organization to recognize the potential value of new external knowledge, assimilate that knowledge, and use it in its own activity (Escribano et al., 2009). It is applicable to all types of innovation, including eco-innovations, as underlined by Ghisetti et al. (2015). The behavior concerning eco-innovation is also strongly dependent on the other types of innovations developed by the firm (product, process, organizational, etc.). These other innovations act as resources which provide a supportive foundation for eco-innovation. This complementarity between eco-innovations and other types of innovations (Milgrom, Roberts, 1990) is emphasized by numerous studies in different economic sectors. In other words, eco-innovation may be technological and rely on innovations of product or process, but it is also often organizational and linked to innovations in the field of coordination between actors within the organization (Laperche, Lefebvre, 2012; Horbach, 2008). In addition, eco-innovation may either be radical, involving deep changes in the organization of production, or incremental, slightly improving the existing production or consumption processes.

Broadly speaking, the analysis of the characteristics of the innovative organization refers to the analysis of its functional and decisional structure. The modes of internal coordination that steer the project and its governance strongly determine the adoption and success of innovations and eco-innovations. The importance of specific forms of management and governance in the eco-innovation process is emphasized by various authors (Wagner, Llerena, 2011). They show the key role of managerial behavior in the development of environmental innovations and the necessary trade-offs between a hierarchical structure and a centralized team-based dynamic in the development of new ideas, strategies and projects (Avadikyan et al., 2001). It reflects the Schumpeterian entrepreneur as innovator (Schumpeter, 1934), who is particularly determining in rural areas, where firms are smaller and governance is more oriented by managers' behavior (Temri, 2011). The importance of governance is particularly recognized in multi-organizational projects. The literature on eco-innovation shows that the type of governance is often a key success factor, as seen for example in the framework of industrial ecology projects where heterogeneous stakeholders collectively develop eco-innovations (Baas, Boons, 2004; Brullot et al., 2014). 


\section{External Factors of the Eco-Innovation System: Local Conditions, Sectoral Context and Regulation}

Because of its distinctiveness in terms of double externalities - notably the existence of environmental spillovers - eco-innovation is particularly sensitive to external factors and to the characteristics of its environment (sectoral, spatial, and regulatory). The analysis of external sources of knowledge used by the organization and, more generally, the material and immaterial resources that allow eco-innovation, raises the question of technological opportunities in a firm's environment (Klevoric 1995) and the sectoral conditions of innovation (Malerba, 2005). These conditions are often mediated by the spatial actor's environment. Low density may influence their modes of coordination and the type of resources they mobilize. In contrast to urban areas, rural areas are characterized by a lack of scale in terms of population and industrial base (McCann, Ortega-Argilès, 2015). Their actors may be far from their economic partners and the consumption centers, therefore making the dissemination of innovation and knowledge more difficult (Esparcia, 2014; Naldi et al., 2015).

Although the literature expresses a general consensus about the role of "economies of agglomeration" in the dissemination of innovation and knowledge (Audrescht, Feldman, 2004), there is still a debate on the nature of externalities - specialization versus diversity - that favor innovation (Galliano et al., 2015). Marshall's model of specialization is based on the idea that knowledge externalities only occur between firms of the same industry, and therefore can only be facilitated by the geographical concentration of actors belonging to similar industries. Unlike Marshall, Jacobs emphasizes that, above all, it is the local variety of activities that enhances knowledge spillovers and ultimately innovation activity. However, location in a rural area and the related low density affect the availability of competencies and resources and limit the strength of the industrial and tertiary base. Therefore, low density has consequences on industrial diversity and on the magnitude of knowledge spillovers. This configuration can make "related variety" externalities (Frenken et al., 2007) more efficient. Related variety can be thought of as the presence in a region of activities that are diverse, but have a degree of technological proximity. The hypothesis maintains that related variety in areas with low density tends to compensate for the smaller agglomeration of activities (Camagni, Capello, 2013; McCann, Ortega-Argilès, 2015; Naldi et al., 2015). Since the use of similar technologies creates a stronger cognitive proximity between firms (Boschma, 2005; Boschma, Frenken, 2011), the presence of related variety creates the positive effect of facilitating knowledge exchange in the region (Neffke et al., 2011). The efficiency of these exchanges is also affected 
by the complementarity of the exchanged knowledge, particularly between an area's pre-existing and new activities (Bathelt, Munro, 2010; Iammarinno, 2011). This suggests that it is not only the agglomeration of activities that determines innovation but also the nature of the activities.

The local context is fundamental for the sectoral system of innovation (Malerba, 2005), particularly in low density areas. The literature on regional development emphasizes the importance of place-specific factors or resources as key factors of innovation, notably in rural areas (Naldi et al., 2015). These factors may be the amenities, materials or inputs that constitute a comparative advantage of an area (McGranahan et al., 2011). But this notion also refers to more non-material characteristics of the area, which can be an inherent part of regional history, such as local knowledge and skills that can't be easily transferred (Asheim, Isaksen, 2002), proximity links, or even "milieu" relationships (Cappello, 2014). The resulting hypothesis suggests that related variety and place-specific factors are two key determinants of eco-innovation in rural areas.

Following the work of Porter and Van der Linde (1995) on regulations and institutional factors, subsequent studies have shown that regulations and public policies play an essential role in the emergence and diffusion of eco-innovations (Rennings, 2000; Horbach et al., 2012). The importance of regulation and public policies stems from the non-tradable nature of the environmental externalities generated by eco-innovations. For firms at the origin of eco-innovations, this non-tradable aspect limits the economic profitability of this innovation. This double externality places the importance of public incentives and regulation at the forefront of eco-innovation dynamics. Regulations and policies act coercively in the sense that they require all companies simultaneously to adopt more ecologically-responsible technologies, but they can also act as incentives, financially encouraging firms to invest in eco-innovation (Horbach, 2008). Incentives should help firms to move beyond the technical and financial constraints and risks identified for the implementation of eco-innovation. These incentives, as well as communication and accompanying measures, are particularly important for agricultural activities in rural areas (Gasmi, Grolleau, 2003). However, the work of Triguero et al. (2013) and Gallaud et al. (2012) suggests that direct public subsidies have little effect in the case of small and mediumsized enterprises (SMEs). And the most positive response to eco-innovation by industrial firms appears to be related to indirect public prompting and the establishment of standards through industrial best practices, rather than strict adherence to regulations (Galliano, Nadel, 2015). Esparcia (2014) also stresses the importance of public officials and their support during the various stages of developing innovation projects, especially in rural areas. 
Consequently, the implementation and development of eco-innovation projects in rural areas are strongly dependent on sectoral, local and regulatory conditions. Because of the consistent importance of organizational factors, the analysis of interactions between the organization and its environment throughout the innovation process is essential to understand the development of eco-innovation projects in rural areas.

\section{Interactions between the Organization and Its Environment: Role of the Path of Eco-Innovation}

As noted earlier, a firm's involvement in innovation is a product of interactions between its own characteristics and those of its environment, and is linked to its absorptive capacity. This is also the case for rural areas (Doloreux et al., 2007). It is a cumulative and path-dependent process, where gatekeepers play a key role. The latter are individuals who make the connection between resources inside and outside of the organization (Abreu, 2011). The general hypothesis is that in rural areas, as a result of the low density of activities, these gatekeepers and, more generally, personal links, play a fundamental role in the adoption process (Esparcia, 2014). Steiner and Mossböck (2014) also show that, in rural areas, innovative firms compensate for the lack of a knowledge base by building cooperation with secondary education institutions and strongly relying on their employees' skills. In a larger sense, the circulation of knowledge raises the question of interaction between local and non-local networks. Although circulation occurs in a local framework, these actors may also be more or less connected to networks outside of their immediate environment (Bathelt et al., 2004). The hypothesis maintains that, contrary to global networks, local networks facilitate the circulation of tacit knowledge which is difficult to codify, and consequently requires direct interactions that are only practical within a certain geographical proximity (Ernst, Kim, 2002). These interactions also require other types of proximity that promote mutual understanding between actors (Balland et al., 2015).

Innovation requires cooperation networks among $R \& D$ actors from firms, and public and private research organizations (Maietta, 2015), as well as sectoral and cross-sectoral links with clients, suppliers and competitors (Klevoric, 1995). Research has emphasized the importance of personal networks and key actors involved in the governance of innovation projects in rural areas (Esparcia, 2014). It has also shown the importance of institutional devices to complement personal networks and their contribution to a project (Guillaume, Doloreux, 2011). The joint mobilization of personal relationships and devices for accessing resources then makes it possible to comprehend the links between individuals and organizations as an emerging 
process of embeddedness (Grossetti, 2015)². These studies stress the key role played by public authorities during the different stages of innovation projects, particularly in rural areas (Esparcia, 2014). The analysis of networks and interactions among public and private actors throughout the various stages is often essential to understand the development process of eco-innovation in rural areas. A primary hypothesis concerning the path of eco-innovation development is that the forms of resource mobilization depend on, and vary with, the various stages of the innovation process (Ferru, 2015; Grossetti, Barthe 2008). This implies that research must consider the learning process, the successive choices made by actors, and the progressive construction of the specific material or non-material assets that support the eco-innovation process (Laperche, Lefebvre, 2012). As a consequence, our analysis primarily examines the relational and geographical dynamics of these processes.

Eco-innovation in rural areas can be viewed as the product of organizational and environmental factors. The organization and the environment co-evolve with the help of localized networks that are essential to the acquisition of resources throughout the development process.

\section{METHODOLOGY AND DATA: MONOGRAPHS OF ECO-INNOVATIVE PROJECTS}

This analysis is based on case studies of eco-innovative projects. First we describe the application of a method, the Quantified Narratives Method (QNM), which is well designed for the study of innovative processes and their dynamics. We then present the criteria of selection and main characteristics of the case studies.

\section{The Use of Quantified Narratives to Build Monographs}

In order to collect and analyze the information about each case we have used QNM, which was designed by French sociologist Michel Grossetti (2011), based on Event-Structure Analysis (Griffin, 2007). The main idea is to foster narratives that will facilitate an understanding of the logic of events and to identify path dependency and the emergence of novelty in processes. Grounded in the literature on social networks, QNM focuses on the role of personal ties in mobilizing partnerships for innovation. Modalities of collaboration are difficult to identify and require the development of specific

2. In this case, entry by relational chains is favored, to understand the role of personal links to access resources. This entry differs from more conventional approaches centered on the actors and their ego network (Wasserman, Faust, 1995). 
approaches to characterize collaboration between actors, particularly personal networks in these collaborations. These networks cannot be identified a priori; the individuals surveyed are best characterized according to relational chains, thereby gradually broadening the scope of individuals. It is particularly helpful to analyze the dynamic of projects and the innovation paths from the perspective of different project stakeholders (Ferru et al., 2015).

QNM has mainly been used to better understand the mechanisms involved in the creation and development of innovative start-ups (Grossetti et al., 2011). With this purpose in mind, we conducted in-depth interviews with the main actors in order to develop monographs for each project. Faceto-face interviews also helped us to understand the mobilization of resources throughout the course of the project.

We collected the following types of information for the three main phases (genesis, creation, stabilization) of the process:

- The nature of external resources acquired by the main actors (financing, inputs, commercial partners, knowledge and advice, etc.).

- The modes of acquisition of these resources, distinguishing between "relational" and "mediation". "Relational" refers to the interviewed actor's existing personal ties with different categories of persons: colleagues, family, friends, locally elected representatives or employees of public institutions (institutional ties), former teachers, or graduates of the same educational establishment (teaching ties), etc. "Mediation" designates a situation where the actor acquires a resource through organizations (including public institutions) or other types of device (markets, medias, banks, advertisements, trade shows, calls for projects...) without mobilizing already existing personal ties.

- The geographical origin of the resources, particularly whether or not they are local (indicator used to assess the degree of spatial anchoring but also the degree of openness).

The specificity of this study is the focus on multi-partnership projects and not on start-ups, a path which is more closely associated with small numbers of individuals. We conducted multiple interviews for each project, in order to collect a cross-section of perspectives among the various actors of the project. Additional data were collected to assess the importance of the governance factor in the eco-innovative projects. In particular, we asked questions about the frequency of meetings between partners, and the issues discussed and modes of decision-making during these meetings. We also collected information about the general characteristics of the project (such as size, type of products, actors involved, legal status of the organization that supports the project). 


\section{Characteristics of the Five Rural and Collective Eco-Innovative Projects Studied}

We used three criteria to select our case studies. The first was location. The projects had to be outside of the large urban areas and outside of their zone of influence as defined by the French National Institute for Statistics (INSEE, 2011). Second, we selected projects that are linked to agriculture and include an environmental dimension, in other words, they should be eco-innovative (Horbach, 2008). Third, the projects had to be carried out by a clearly identified organization. These projects emerged from local private actors with the support of local public actors. In a second stage, the private actors have created an organization (cooperative, association, firm) dedicated to the management of the project, of which farmers are always shareholders.

The projects were identified using different sources of information: local and agricultural press, exploratory interviews with representatives from local government, and information from other projects of INRA (the French National Institute for Agricultural Research), particularly those concerning agro-ecology. Combining this information helped us identify the projects that local actors recognize as interesting and representative of eco-innovative projects in agriculture and the agri-food industry.

Map 1 shows the location of the projects. Four projects are located in the Aveyron department, and one, Qualisol, is in the Gers department. Aveyron and Gers are among the most remote rural departments in France, according to the European urban-rural typology (EDORA, 2010), and are highly structured by agriculture. Located south of the mountain range, the "Massif Central", Aveyron specializes in cattle and sheep breeding (meat and milk), which represented 80\% of production by value in 2010 (Agreste, 2011a). Original agricultural products are numerous in Aveyron, with iconic products like Roquefort (cheese). In the valleys and hills of the Gers, production is more diversified and the dominant products are sunflowers, soya, fattened ducks and wine (Agreste, 2011b).

Among these projects, three (Régalou, Bergers du Larzac, Qualisol) are agri-food projects, whereas two (Prometer and CAE Biogaz) are renewable energy projects (collective methanation). The three agri-food projects are older and more advanced than the two methanation projects. Although they all involve farmers, they are differentiated by their size. The largest, Qualisol, involves 300 farmers producing organic cereals, whereas the smallest (Bergers $d u$ Larzac) involves 23 farmers producing conventional and organic sheep milk for a cooperative that makes cheese. Table 1 summarizes the main characteristics of each project. 


\section{Map 1 - Location of the projects}

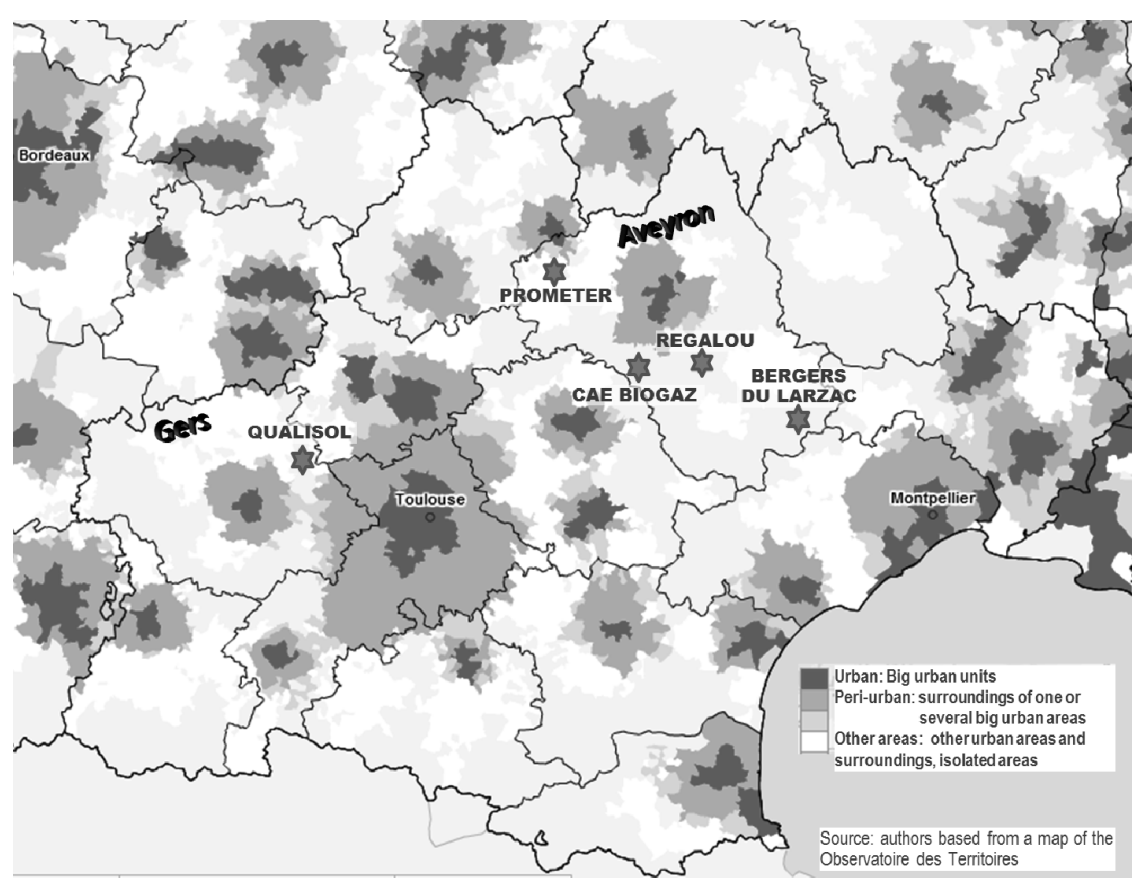

Table 1 - Main characteristics of the projects

\begin{tabular}{|l|l|l|l|l|l|}
\hline Project & Type & $\begin{array}{l}\text { Organization } \\
\text { that carries } \\
\text { out the project }\end{array}$ & Production & Beginning & $\begin{array}{l}\text { Environmental } \\
\text { dimension }\end{array}$ \\
\hline Régalou & Agri-food & $\begin{array}{l}\text { Unincorporated } \\
\text { association } \\
\text { (20 farmers, } \\
\text { 36 bakers, } \\
2 \text { mill owners, } \\
1 \text { cooperative })\end{array}$ & $\begin{array}{l}\text { Bread made } \\
\text { with local } \\
\text { wheat and } \\
\text { flour }\end{array}$ & 1992 & $\begin{array}{l}\text { Sustainable and } \\
\text { agro-ecological } \\
\text { wheat production }\end{array}$ \\
\hline $\begin{array}{l}\text { Bergers } \\
\text { du Larzac }\end{array}$ & Agri-food & $\begin{array}{l}\text { Cooperative } \\
\text { (23 farmers })\end{array}$ & $\begin{array}{l}\text { Sheep milk } \\
\text { cheese }\end{array}$ & 1993 & $\begin{array}{l}\text { Conventional and } \\
\text { organic cheese }\end{array}$ \\
\hline Qualisol & Agri-food & $\begin{array}{l}\text { Cooperative } \\
\text { [300 organic } \\
\text { farmers })\end{array}$ & $\begin{array}{l}\text { Cereals and } \\
\text { legumes }\end{array}$ & 2000 & $\begin{array}{l}\text { Organic cereals } \\
\text { and legumes }\end{array}$ \\
\hline Prometer & $\begin{array}{l}\text { Energy } \\
\text { production }\end{array}$ & $\begin{array}{l}\text { Firm [70 farmers, } \\
\text { a public bank, a firm] }\end{array}$ & $\begin{array}{l}\text { Biogas and } \\
\text { digestate }\end{array}$ & 2005 & $\begin{array}{l}\text { Renewable } \\
\text { energy, waste } \\
\text { recycling }\end{array}$ \\
\hline CAE Biogaz & $\begin{array}{l}\text { Energy } \\
\text { production }\end{array}$ & $\begin{array}{l}\text { Firm [22 farmers and } \\
\text { citizens, a regional } \\
\text { agency, two other } \\
\text { firms }\end{array}$ & $\begin{array}{l}\text { Electricity, } \\
\text { heat and } \\
\text { digestate }\end{array}$ & 2008 & $\begin{array}{l}\text { Renewable } \\
\text { energy, waste } \\
\text { recycling }\end{array}$ \\
\hline
\end{tabular}


The environmental dimension of each project is different. Methanation produces renewable energy; Qualisol is involved in the production of organic cereals and legumes by a cooperative which also makes conventional cereals. Bergers $d u$ Larzac is also a cooperative with both organic and conventional production (cheese). And the wheat for Régalou bread is cultivated using sustainable farming techniques, and the association maintains an obligation to reincorporate a portion of the participating farms' manure as fertilizer.

The first interviews were conducted with a project leader involved particularly in the emerging phase. Additional interviewees were usually identified during the first interview or the following interviews, in a relational chains method. The number of interviews varies from two for Bergers $d u$ Larzac to five for Qualisol. Half were conducted in person and the other half by telephone. Seventeen interviews of approximately an hour and twenty minutes were conducted in 2015, with the exception of Qualisol, whose interviews occurred in 2014. After each interview a transcription was sent to each person for validation and possible modifications.

The projects were still in progress at the time of the study. QNM allowed us to distinguish different phases (genesis / emergence, creation, and stabilization). The first phase of emergence, or genesis, is the phase of ideas and reflections. The second phase is creation, which begins with the creation of the formal organization and the effective launching of the project. There are differences between this phase of the food projects and that of the biogas projects: in the agri-food projects this second phase is expressed as effective action represented by the first production and marketing, in the methanation project it is the launching of the first study by the formal organization. The third phase of stabilization begins when a major event occurs and initiates a new turn in the project.

\section{RESULTS: THE ROLE OF THE CHARACTERISTICS OF THE ORGANIZATION AND ITS ENVIRONMENT}

This part is about the results of our study. We will start by explaining which internal factors have affected the projects and their progress and how they have impacted these. Then, we will present the role of external factors. Last sub-section is dedicated to the analysis of the projects' trajectories in terms of resources and of their means of acquisition (personal ties or mediation). The objective is to highlight how internal resources and the environment of the organization act and interact with each other. 


\section{Internal Resources and Governance of the Organization: Two Key Factors in a Project's Development}

This sub-section is dedicated to the analysis of some internal characteristics of the organizations that carry out the projects. It focuses on the role of absorptive capacity and governance.

\section{The Mobilization of Internal Resources}

The emergence of these projects is linked to leaders with a strong ability to mobilize resources. These leaders are usually the principal actors, with both technical and organizational capabilities, who develop the organization that undertakes the project (cooperative, association, firm). The main challenge for these projects is to generate technical and organizational innovations that reinforce internal resources and strengthen the absorptive capacity. This requires them to continuously improve their offerings with new products (for agri-food chains) or to adjust their product to changes in the market, regulations, and local conditions (adjustment of the size and technical choices for methanation projects). They also develop inner-organizational innovations to improve efficiency, such as contractual agreements between actors in the agri-food projects.

Some examples illustrate how internal resources reinforce the absorptive capacity of eco-innovative projects. In the case of Régalou (bread production in Aveyron) a group of local actors, a mill owner, a baker, and an agricultural cooperative, provide information about changes in context, the market, and techniques in their respective activities. They also play a major part in the articulation between this information and the evolution of the organization's strategy. For the methanation projects, it is also a small group of individuals (citizens, farmers and a local elected representative) that provides the basic knowledge necessary to develop the multi-partnership project. For Qualisol and Bergers du Larzac, the dynamics have changed over time. In the early years, the absorptive capacity relied on very few individuals (mostly the founder for Berger du Larzac), but it is now more decentralized, due to the expansion of the activity and to increases in the number of employees. Technical and organizational innovations complement one another, as seen in the Qualisol project, where the increasing size of organic storage capacities is associated with renewed services to organic farmers.

We see that the ability to constantly innovate seems to be closely tied to a small number of individuals within the organization. These individuals are also the organizers of project governance. 


\section{Strong Governance throughout the Course of the Project}

Governance is important in every project and is a key factor of project dynamics ${ }^{3}$. However, its form differs according to the project.

Régalou has been governed almost from the beginning by a core administrative group, which includes the cooperative, the two mill owners and representatives from the farmers and the bakers. They all attend each meeting (every other month) which is open to all kinds of discussion, from the problematics of wheat production to the marketing strategy and the price of wheat, or the flour and bread.

Governance within Bergers du Larzac is even more demanding. Every farmer is part the governing board and is invited to board meetings, which are held every six weeks. After twenty years of existence, the average participation rate at meetings is still $80 \%$. Everything is discussed, from milk production to cheese distribution. Recently, to facilitate governance, an "administrative group" was created, with the President of the cooperative and eight representatives of the farmers. This group meets every two weeks and remains open to any farmer. In addition, semi-annual visits to the farms are organized, particularly to increase discussions between farmers.

For the two methanation projects, meetings are less regular, but occur at least once a year or on demand when decisions (technological or organizational) have to be made, or difficulties arise. For Prometer, a working group of ten individuals was at the core of the project until 2013. This included primarily farmers, with an advisor from the Chamber of Agriculture and a representative from a public bank. All the farmers interested in the project have been gathering for a meeting at least once a year since 2007 and regularly receive information via a newsletter. In 2013, a firm was created to manage the agricultural section of the project, where each farmer is a shareholder. Since this was established, governance has been strengthened (a board meeting each month and a meeting with all farmers twice a year). A second firm was also created with farmers as shareholders, but also including the public bank and the firm in charge of building the methanizer. The board of this second firm meets once every three months. For the second methanation project (CAE Biogaz) the evolution of governance follows the same path, even if the nature of the actors involved differs.

The governance dimension emphasizes the importance of fully involving all the actors in the technical and organizational choices that must be made during the project. The need for frequent meetings between all the actors

3. The governance is more complicated to analyze in the case of Qualisol because the project is mainly a conventional cooperative without specific rules for organic production. 
in order to share knowledge decreases as the project progresses. Concerns about efficiency and increases in the project size encourage the adoption of "representative" governance centered on a smaller number of core actors that represent the diversity of the partners involved.

The internal characteristics of the organization that leads each project play a clear role in its success. The ability to combine internal resources and acquire new ones to reinforce the absorptive capacity of the organization is crucial. In each project, a small number of individuals - even sometimes just one person - are at the center of this reinforcement process. These entrepreneurs also organize the governance of the project. The latter is always important, notably in the early stages, and is not only designed to guarantee the support of the members for the project target, but also to collectively define these targets.

\section{The Determining Role of External Factors of the Organization}

In this sub-section, we analyze the role of several external factors of the project's creation and dynamic. These factors are local - place-specific and related variety - and non-local (demand and public policies).

\section{Place-Specific Factors and Related Variety: The Importance of the Local Context}

The local context was a determining factor from the beginning of the projects. In each case, specific local problematics led local actors to search for ways to incorporate local resources in the creation of a new activity. The actors at the origin of the projects are not always farmers, but there are always local actors interested in creating a new project in their local area, in part for economic reasons, but also because of their concerns for their living environment. Based on the evaluation of place-specific factors, these collective projects involve various types of actors in order to mobilize related resources. The genesis and developmental phases of all the projects benefited to some degree, sometimes decisively, from the resources provided by a departmental agricultural office (Chambre d'agriculture).

\section{The Existence of Specific Local Problematics Concerning Agriculture and the Agri-Food Industry}

The role of specific local problematics is obvious in the four projects in the Aveyron, where most agriculture is oriented towards livestock production. This type of production faces significant problems maintaining activities and encouraging new installations, particularly after the economic difficulties 
faced by livestock farmers over the last few years. Methanation is an opportunity for livestock farmers to create economic value from manure by converting it into a powerful fertilizer (digestate), used in their own fields. It also provides dividends for shareholders of these projects. For Régalou, there was a specific problematic in the valuation of arable land by livestock farmers in a hilly area where climatic conditions add significant constraints. This was the starting point that engendered the idea that local bread could be a way to add value to local resources and create a new product from Aveyron. For Bergers du Larzac, it was the issue of the Roquefort industry's lock-in that convinced farmers to commit themselves to the project. Industry rules made it nearly impossible for farmers, new or existing, to become a new milk supplier for Roquefort. Another factor encouraging commitment to the project was a perception that the cheese industry's power in the Roquefort organization was increasing, leaving some farmers worried about the future of milk producers.

\section{The Role of Related Variety in Combining Local Resources}

Related variety - the presence in an area of economic activities with a certain technological proximity - is important for the projects because they have a strong dependence on existing local activities and on the ability of the projects' leaders to combine the resources provided by these activities to create a new one. The sectoral relationship brought three major elements to the agri-food projects: existing agricultural production, facilities and assets, and know-how.

For Régalou, a number of grain crops (particularly rye) were already cultivated in the area by the livestock farmers involved at the beginning of the project, although these crops were cultivated mainly for feed. Growing wheat to make bread did not require new investment from livestock farmers who already had the equipment and know-how enabling them to produce the quality of wheat expected by millers. At the same time, they could engage in environmental efforts by using a portion of their manure to fertilize wheat. Other actors involved in the Régalou project also have assets and know-how that facilitated the development of the project. The livestock cooperative contributed with existing collection and storage capacities and strongly supports the project as an original effort at diversification linked to the local context. Similarly, two local mill owners with existing facilities were involved. For the actual bread making, Regalou also took advantage of the presence and know-how of local traditional bakers.

Qualisol was a conventional grain crop cooperative. At the beginning of the 2000s, conversions to organic farming were increasing and farmers 
from Qualisol and elsewhere were looking for market opportunities for their production. Two individuals (an employee and an influential farmer in the cooperative) have played a key role in convincing the cooperative board to participate in organic production by converting an old conventional silo to store organic crops. The coexistence in the cooperative of both conventional and organic activities appears to be an important lever in the development of organic activity, because it facilitates the process of convincing conventional grain buyers to try organic cereals and become regular organic customers.

Bergers du Larzac began as an alternative to the Roquefort agri-food chain (sheep milk cheese production). The main founder was a previous supplier for Roquefort who left with the founding of Bergers $d u$ Larzac. The other founding members were also sheep farmers. As a consequence, the group already had know-how concerning breeding and - for most of them - milk production, and some knowledge of cheese production. They chose a cheese (Pérail) that was traditionally produced by farms outside of the period when they normally supplied milk for Roquefort. This choice allowed them to benefit from local knowledge in production of the cheese, even if production on a large, or "industrial", scale was a new technical challenge. Although they benefited from the existing facilities of a former Roquefort cheese factory, it should be noted that they were relatively inexperienced in the production of cheese and have only gradually acquired all the materials and know-how needed.

The agglomeration of supply and demand in the territory has been a determining factor in the development of the two methanation projects. At the beginning, the two projects will use manure from local breeders in close proximity to reduce transportation costs, but manure is a relatively weak input in methanogenic systems and other inputs have to be used. CAE Biogas will use green waste from surrounding municipalities and food waste from a local grocery. Agglomeration is even more strategic for Prometer, as a larger project that will only be profitable if other materials are used, and if those materials come from nearby municipalities (lower transport costs). The waste from local agri-food firms (especially from the meat processing industry) is a crucial element. These firms are particularly interested in this project because it will provide a new local and inexpensive solution for processing their waste, which does not exist today. CAE Biogaz will also benefit from the presence of a local sawmill (wood industry) which will house a drying shed that uses heat from the methanizer.

It is clear that without the existing local activities these projects would have been impossible. They all take advantage of a new combination of local resources, each in their own way depending on the type of project (methanation or agri-food). 


\section{The Role of Demand}

Many authors emphasize the role of demand in the development of innovations and eco-innovations. It was a driving factor for the methanation projects where profitability is closely tied to the feed-in price of the electricity or biogas. The guarantee of a market and a high feed-in price led the actors to consider developing methanation. But it was different for the three agrifood projects because the potential market was largely unknown. The founders knew that there was a possible demand but had no precise evaluation of that demand and, particularly, no real sense of the figures it could generate. Due to their professional experience, they had an idea of the type of products that could interest consumers, but they could not set a precise benchmark before starting.

Nevertheless, we can see that for two of the projects, it is the positive response from the market which helped to amplify the projects by generating investment for developing technical and organizational innovations. For Qualisol, success can be seen in the construction of new organic silos with increased storage capacity. For Bergers $d u$ Larzac, strong product sales have stimulated the development of a range of cheese, including organic cheese, along with numerous key innovations. These projects reinforce the notion that market demand has an important role in the development and adoption of eco-innovation projects (in other words, increasing return to adoption).

\section{Regulations and Public Policies as Triggering Factors for All the Projects}

Regulations and public policies were determining factors at some point in the development of all five of the projects. Their emergence was, directly or indirectly, linked to national or European policies. In the Bergers du Larzac, Qualisol and Prometer projects this link was direct. The Prometer project is a direct consequence of the European policy for the promotion and dissemination of collective methanation. It is in the framework of this policy that the Montbazens area was identified as particularly promising for methanation, and that local actors were informed of their territory's potential. Qualisol grew out of a national plan for conversion to organic farming that prompted many of the territory's farmers to adopt organic practices. For Bergers $d u$ Larzac, the main founder of the cooperative has launched the project (that he had in mind for a long time) thanks to a national training program for the creation of activities in rural areas. The influence of policies and regulations in the cases of Régalou and CAE Biogas was more indirect. Initial ideas linked to Régalou are related in part to a measure concerning land use in the framework of the Common Agricultural Policy, which encourages livestock 
farmers to develop new uses for fallow fields. The origins of CAE Biogaz benefited from assurances of profitability through a national French policy on renewable energies that guaranteed a high feed-in price for the production of renewable energy.

The dependence on regulations and public policies seems to diminish gradually as the projects develop. This growing autonomy may eventually result in a move towards a public-private partnership. For example, Qualisol has taken measures to be the operator of a public agri-environmental measure to reduce the impact of agricultural pollution on water quality (Del Corso et al., 2015). It has also developed partnerships with public research.

The importance of regulation and public policies as an environmental factor of innovation is highlighted in our theoretical framework. Their effects on the projects we studied may be mitigated, but they are undeniable.

External factors also explain the emergence of these projects and their development. The local context is decisive in the early stages. Each project is indeed a response to a local problematic in agriculture or the agri-food industry, and is therefore designed to address this. This may explain the significant use of local resources provided by already existing activities, even if this local dimension is weaker for methanation projects. Regulation and public policies are also triggering factors for each project and sometimes intervene later in their development by creating new barriers or, on the contrary, new opportunities for the project's development. Among these opportunities some are related to demand. A positive response from demand is also important for the project's development, but not for their genesis. Surprisingly, project leaders never carried out market studies before launching the activity.

\section{Networks and Co-Evolution}

After being launched by a small group of individuals, the projects have grown progressively by mobilizing external resources. Within the QNM framework, an external resource can be defined as any new element that is mobilized during a process. It mainly includes: financial resources, workforce, equipment, advice, expertise, partners, suppliers and clients. There are two ways to obtain these resources: personal ties (local or not) - in other words thanks to a person you already know - or mediation devices.

\section{The Development of Professional Networks throughout the Course of the Projects}

Personal ties refer to already existing relationships with colleagues/co-workers within or outside the organization. They also refer to relationships with 
clients, suppliers, subcontractors, competitors, etc. These ties are developed in various professional contexts. For farmers, they tend to be direct relationships with other farmers and with individuals from a wide range of professional organizations (cooperatives, chambers of agriculture, professional training organizations). The dynamic is similar for the other professions involved in the project, such as the mill owners and bakers in Régalou. These professional links encourage the exchange of ideas and the commitment of individuals involved in the projects, and they become interwoven with links that foster exchanges between various activities.

Advisors from the local agricultural offices (Chambre d'agriculture) are important for most of the projects. At the inception of Qualisol and Régalou, the advisors were a determining factor in helping to identify potential new members and bring them into the project. These offices also provided important advice and training that helped newly involved farmers to acquire new technical skills. In the methanation projects, the participation of agricultural advisors in the studies concerning project feasibility was particularly pertinent. In the case of Régalou, the local Chamber of trade (Chambre des métiers et de l'artisanat) has been a determining factor through training, advice and access to its local laboratory, which enabled bakers to create new recipes. In the Qualisol project, personal links with other cooperatives and the Regional Federation of Cooperatives have provided access to training programs and technical support. Bergers $d u$ Larzac has taken advantage of the local professional organizations created by the farmers of $\mathrm{Larzac}^{4}$. Although a major part of their start-up funding came from participatory loans, there were also economic inputs from local farmers who knew the founder and a local union of sheep breeders. Throughout the course of the project, word of mouth helped to assemble experts and advice to solve specific problems.

\section{Non-Professional Links as a Complementary Support for the Eco-Innovative Projects}

Besides professional networks, other personal links were also important for the projects. In our study we found three main categories of non-professional ties: family ties, friendship ties and institutional ties. Institutional ties are already-existing links with employees of public institutions or locally elected representatives involved in this institution (mayor, regional councilor, etc.). Some ties with researchers (academic ties) have been observed but remain very rare in these projects.

4. AVEM (Association Vétérinaires Eleveurs du Millavois) and Ovi-test, a cooperative for insemination. 
With regard to these institutional links, those that we observed are mostly relationships with locally elected representatives that provide access to government-sponsored subsidies, logistics, or administrative support. This type of link is more significant in the methanation projects where local elected representatives are involved. For example, for Prometer, the President of an inter-community association, Communauté de Communes, supported the project's inception by financing an initial study and organizing meetings. For the agri-food projects, the interventions from institutional actors have been intermittent and primarily oriented towards solutions to specific problems, nevertheless, these interventions are often determining factors. In all the projects these local links have been a way to access resources at higher levels (department, region and country).

Family and friendship ties are not particularly numerous. Two of the cofounders of Bergers du Larzac were friends. The main founder also had a friendly relationship with neighboring farmers that helped him find advice and support. This was also the case for Qualisol, where a number of "pioneer" organic farmers and employees of the cooperative were encouraged by friendship and family ties in their decision to establish this organic activity.

Simple neighborhood links also provide opportunities of access to significant resources. For example, the founder of Bergers $d u$ Larzac heard about the training program that convinced him to launch the project from someone who lived close to his farm. In 2000, the cooperative began organic production because another of the founder's neighbors who managed the French division of an organic cheese distributor was able to provide access to the German market.

Contrary to what we expected, there have been practically no links with researchers, even if this is now changing for Qualisol and Bergers du Larzac.

With the influence of these networks, there is a co-evolution of the organization leading the project and its environment. These activities, which benefit the local area, need specific resources and solutions. For these projects, professional organizations and public administrations have used their existing resources or dedicate new ones to help project leaders solve problems. Even when these interventions are intermittent, they can be a determining factor.

\section{A Dynamic Combination of Personal Links and Mediation Devices}

The table below summarizes the trajectory of the cases in terms of acquisition of resources. It was obtained by coding for each project the sequences of access to external resources, thanks to QNM methodology. A total of 169 sequences were identified. For each sequence, the means of acquisition 
of the resource was coded. We distinguish three main categories: professional ties, non-professional ties and mediation (resources acquired without using already-existing relationships with other individuals).

Table 2 - Means of acquisition of the resources according to the projects' phase

\begin{tabular}{|l|c|c|c|c|c|}
\hline & $\begin{array}{c}\text { Professional } \\
\text { ties }\end{array}$ & $\begin{array}{c}\text { Non-professional } \\
\text { ties* }\end{array}$ & $\begin{array}{c}\text { Mediation } \\
\text { devices** }\end{array}$ & Unknown & Total \\
\hline Genesis (values) & 25 & 14 & 31 & 0 & 70 \\
\hline Genesis (\%) & 35.7 & 20.0 & 44.3 & 0.0 & 100 \\
\hline Creation (values) & 22 & 9 & 30 & 0 & 61 \\
\hline Creation (\%) & 36.1 & 14.8 & 49.2 & 0.0 & 100 \\
\hline Stabilization (values) & 17 & 2 & 18 & 1 & 38 \\
\hline Stabilization (\%) & 44.7 & 5.3 & 47.4 & 2.6 & 100 \\
\hline Total (values) & 64 & 25 & 79 & 1 & 169 \\
\hline Total (\%) & 37.9 & 14.8 & 46.7 & 0.6 & 100 \\
\hline
\end{tabular}

* quasi-exclusively family, friends, institutional ties (with elected representatives and/or employees of public institutions).

**Acquisition of resources without mobilizing personal ties.

This summary confirms that personal networks (professional and nonprofessional) are strong determinants for the projects. They account for more than half the 169 external resources identified. Professional ties are particularly important, providing more than one third of the resources. They play a key role from the genesis phase, which strengthens as the projects progress. On the contrary, the importance of the other types of networks is quite strong at the very beginning but decreases afterward, which is consistent with the results of Schutjens and Stam (2003) about new firms' networks evolution. In our study, non-professional ties are often institutional. This combined influence of professional and institutional ties is also observed by Esparcia (2014) or Grossetti and Barthe (2008) in their studies. However, our results are different about decoupling, which may be defined as the tendency of the process to become autonomous from its original context. Other studies tend to show a diminishing role of professional networks and a significant growth of mediation devices in the second and third phase of the projects, which is not the case in our study. This can be explained by the fact that these projects are collective projects and not start-ups based on one or two people who first use their personal network to start a business. Mediation mostly provides financing (loans or subsidies), occasional services (such as consultancy or technical support) and equipment. It more rarely provides new customers, new partners and training. This result is consistent with that of Grossetti and Barthe (2008) regarding the nature of resources 
acquired through mediation. Concerning the relative stability of access to resources thanks to mediation, this result suggests that, if mediation is an undeniable resource provider for projects, personal networks are equally essential throughout the process, notably professional ties.

We can conclude that these projects are strongly embedded in their local environment. Their leaders take advantage of place-specific factors and local related-variety, notably at the beginning of the projects. Non-local environmental factors such as demand and public policies also influence the projects' trajectory. But the environmental characteristics alone do not explain the existence of the project and their dynamic. The internal characteristics of the organization that carries out the project are also a determining factor, along with its ability to use professional and non-professional ties to acquire external resources throughout the projects' course.

\section{CONCLUSION}

This article is aimed at analyzing the relationship between eco-innovation and low density of economic activities. The goal of this analysis is to provide a better understanding of the factors and mechanisms in the emergence and development of eco-innovative projects in rural areas. In a context of diverse projects and agri-environmental strategies, this analysis draws attention to the cognitive and relational constraints specific to rural areas. It also reinforces the idea of smart rural development that is specific to low density areas. The innovations that we observed, based on specific resources such as agro-ecological, are also a good example of the rural economic actors' faculty for innovation. Even if these innovations do not concern highly technological fields, our study shows that they tend to combine both technological and organizational innovations, but also institutional and social dynamics that affect the project's course.

The empirical study shows major trends and regularities in the determinants of eco-innovation in rural areas. In the beginning, the absorptive capacity of the organization, and its governance, has a strong impact on the development path of eco-innovative projects. These internal factors are reinforced by specific characteristics of the external environment, notably the presence of place-based factors and related variety, as defined by Frenken et al. (2007). The innovation process in rural areas strongly relies on personal relationships and central actors, combined with the determinant use of institutional devices, local resources and external relational networks.

In terms of dynamics, the means of acquiring external resources evolves throughout the project, but not as much as expected, given the results of 
Esparcia (2014). Professional networks remain the main path to external resources throughout the course of the projects. The importance of other networks (friends, family, locally-elected representatives, etc.) gradually decreases. Surprisingly, the importance of mediation remains relatively stable. This indicates no progressive decoupling of the projects from the familiar relational environment of its members. This finding is reinforced by the fact that the actors use personal ties even when seeking remote resources (outside of the region). This tendency continues during the phases of creation and stabilization when the origin of resources often expands beyond the local environment. The weaker dependence on proximity suggests a progressive decoupling from the local context in a manner that is consistent with the literature (Grossetti, 2011). It also emphasizes the fact that local resources are determinant but not sufficient, which is again consistent with the literature (Ferru et al., 2015; Boschma, 2005).

At this point, based on a few cases in a specific region, our results cannot be extended to all rural regions and the diversity of their structural characteristics. According to the typology of McCann and Ortega-Argilès (2015), the region of Aveyron remains close to urban areas and thus is not particularly isolated. However, this type of region is very present in Europe given the extent of urbanization. As a consequence, the drivers of eco-innovation in rural areas emphasized by our study (related variety of local activities, connectivity, and embeddedness) remain highly relevant to the determination of public policies addressing rural innovation.

\section{REFERENCES}

ABREU, M. (2011), Absorptive Capacity in a Regional Context, in Cooke, P. (ed.) Handbook of Regional Innovation and Growth, Cheltenham, Northampton, Mass, Edward Elgar., 211-221.

AGRESTE (2011a), Aveyron, Agreste données, 59.

AGRESTE (2011b), Gers, Agreste données, 61.

ASHEIM, B. T., ISAKSEN, A. (2002), Regional Innovation Systems: The Integration of Local "Sticky" and Global "Ubiquitous" Knowledge, Journal of Technology Transfer, 27, $77-86$.

AUDRETSCH, D. B., FELDMAN, M. P. (2004), Knowledge Spillovers and the Geography Of Innovation, in Henderson, J. V., Thisse, J. E., Handbook of Regional and Urban Economics, Vol. 4, London, Elsevier, 2713-2739.

AVADIKYAN, A., LLERENA, D., OSTERTAG, K. (2001), Organizational Mechanisms in Environmental Management: An Evolutionary Analysis Confronted with Empiric Facts, International Journal of Environmental Technology and Management, 1(1-2), 45-60. 
BAAS, N. W., BOONS, F. A. (2004), An Industrial Ecology Project in Practice: Exploring the Boundaries of Decision-Making Levels in Regional Industrial Systems, Journal of Cleaner Production, 1072-1085.

BALLAND, P. A., BOSCHMA, R., FRENKEN, K. (2015), Proximity and Innovation: From Statics to Dynamics, Regional Studies, 49(6), 907-920.

BARTHE, J. F., BESLAY, C., GROSSETTI, M. (2008), Choix de localisation et mobilisation des ressources dans la création d'entreprises innovantes, Géographie, économie, société, 10(1), 43-60.

BATHElT, H., MAlmberG, A., MASKElL, P. (2004), Clusters and Knowledge: Local Buzz, Global Pipelines and the Process of Knowledge Creation, Progress in Human Geography, 28(1), 31-56.

BATHELT, H., MUNRO, A. K. (2010), Innovation Linkages in New and Old Economy Sectors in Cambridge-Guelph-Kitchener-Waterloo (Ontario), SPACES online, 2010-05(8), $1-19$.

BOSCHMA, R. (2005), Proximity and Innovation: A Critical Assessment, Regional Studies, 39(1), 61-74.

BOSCHMA, R., FRENKEN, K. (2011), Technological Relatedness and Regional Branching, in Bathelt, H., Feldman, M. P., Koegler, D. F. (eds), Beyond Territory: Dynamic Geographies of Innovation and Knowledge Creation, Oxon, New-York, Routledge, 64-81.

BRULlOT, S., MAILlEFERT, M., JOUBERT, J. (2014), Stratégies d'acteurs et gouvernance des démarches d'écologie industrielle et territoriale, Développement Durable et Territoires 5(1).

CAMAGNI, R., CAPELlO, R. (2013), Regional Innovation Patterns and the EU Regional Policy Reform: Toward Smart Innovation Policies, Growth and Change, 44(2), 355-389.

CAPELLO, R. (2014), Proximity and Regional Innovation Processes: Is There Space for New Reflections?, in Torre, A., Wallet, F. (eds.), Regional Development and Proximity Relations, Cheltenham, Northampton, Mass, Edward Elgar, 163-194.

COHEN, W. M., LEVINTHAL, D. A. (1990), Absorptive Capacity: A New Perspective on Learning and Innovation, Administrative Science Quarterly, 35(1), 128-152.

DEL CORSO, J. P., KEPHALIACOS, C., PlUMECOCQ, G. (2015), Legitimizing Farmers' New Knowledge, Learning and Practices through Communicative Action: Application of an Agro-Environmental Policy, Ecological Economics, 117, 86-96.

DEL RÍO GONZÁLEZ, P. (2009), The Empirical Analysis of the Determinants for Environmental Technological Change: A Research Agenda, Ecological Economics, 68(3), 861-878.

DOLOREUX, D., DIONNE, S., JEAN, B. (2007), The Evolution of an Innovation System in a Rural Area: The Case of La Pocatière, Québec, International Journal of Urban and Regional Research, 31(1), 146-167.

EDORA (2010), European Development Opportunities for Rural Areas, Draft final report, ESPON, Luxembourg.

ERNST, D., KIM, L. (2002), Global Production Networks, Knowledge Diffusion, and Local Capability Formation, Research Policy, 31(8-9), 1417-1429.

ESCRIBANO, A., FOSFURI, A., TRIBÓ, J. A. (2009), Managing External Knowledge Flows: The Moderating Role of Absorptive Capacity, Research Policy, 38(1), 96-105. 
ESPARCIA, J. (2014), Innovation and Networks in Rural Areas: An Analysis from European Innovative Projects, Journal of Rural Studies, 34, 1-14.

FERRU, M., LIBERAT, N., GUIMOND, B., DEPRET, M.-H. (2015), Deconstructing the Collective Process of Environmental Innovation: A Case Study of Poitou-Charentes Companies, Journal of Innovation Economics ES Management, 16(1), 139-170.

FRENKEN, K., VAN OORT, F., VERBURG, T. (2007), Related Variety, Unrelated Variety and Regional Economic Growth, Regional studies, 41(5), 685-697.

GALLAUD, D., MARTIN, M., REBOUD, s., TANGUY, C. (2012), La relation entre innovation environnementale et réglementation: une application au secteur agroalimentaire français, Innovations, 37, 155-175.

GALliANO, D., MAGRINI, M. B., TRIBOULET, P. (2015), Marshall's versus Jacobs' Externalities in Firm Innovation Performance: The Case of French Industry, Regional Studies, 49(11), 1840-1858.

GALLIANO, D., NADEL, S. (2015), Firm's Eco-Innovation Intensity and Sectoral System of Innovation: The Case of French Industry, Industry and Innovation, 22(6), 467-495.

GASMI, N., GROLlEAU, G. (2003), Spécificités des innovations environnementales - une application aux systèmes agroalimentaires, Innovations, 18, 73-89.

GHISETTI, C., MARZUCCHI, A., MONTRESOR, S. (2015), The Open Eco-Innovation Mode: An Empirical Investigation of Eleven European Countries, Research Policy, 44(5), 1080-1093.

GRIFFIN, L. J. (2007), Historical Sociology, Narrative and Event-Structure Analysis: Fifteen Years Later, Sociologica, 3, 1-17.

GROSSETTI, M. (2015), Note sur la notion d'encastrement, SociologieS [En ligne], Théories et recherches, http://sociologies.revues.org/4997

GROSSETTI, M. (2011), Les narrations quantifiées. Une méthode mixte pour étudier des processus sociaux, Terrains $\mathcal{E}$ travaux, 19(2), 161-182.

GROSSETTI, M., BARTHE, J.-F. (2008), Dynamiques des réseaux interpersonnels et des organisations dans les créations d'entreprises, Revue française de sociologie, 49(3), 585-612.

GROSSETTI, M., BARTHE, J.-F., CHAUVAC, N. (2011), Studying Relational Chains from Narrative Material, Bulletin of Sociological Methodology/Bulletin de Méthodologie Sociologique, 110, 11-25.

HORBACH, J. (2008), Determinants of Environmental Innovations, New Evidence from German Panel Data Sources, Research Policy, 37, 163-173.

HORBACH, J., RAMMER, C., RENNINGS, K. (2012), Determinants of Eco-Innovations by Type of Environmental Impact: The Role of Regulatory Push/Pull, Technology Push and Market Pull, Ecological Economics, 78, 112-122.

IAMMARINNO, S. (2011) Regional Innovation and Diversity, in Cooke, P., Asheim, B., Boschma, R., Martin, R., Schwartz, D., Tödtling, F., (eds) Handbook of Regional Innovation and Growth, Cheltenham, Northampton, Mass, Edward Elgar, 143-154.

INSEE (2011), Le nouveau zonage en aires urbaines de 2010, INSEE première, 1374, 4 p. KLEVORICK, A. K., LEVIN, R. C., NELSON, R. R., WINTER, S. G. (1995), On the Sources and Significance of Interindustry Differences in Technological Opportunities, Research Policy, 24(2), 185-205. 
Eco-innovations in rural territories: Organizational dynamics and resource mobilization in low density areas

LAPERCHE, B., LEFEBVRE, G. (2012), Stratégie environnementale, innovation et mutation des firmes, Innovations, 37, 127-154.

LENNERT, M., ROBERT, J. (eds) (2007), Scenarios on the Territorial Future of Europe, Report for the ESPON Project 3.2.

LEVIDOW, L., (2015), European Transitions towards a Corporate-Environmental Food Regime: Agroecological Incorporation or Contestation?, Journal of Rural Studies, 40, 76-89. MAGRINI, M. B, GALliANO, D. (2012), Agglomeration Economies, Firms' Spatial Organization and Innovation Performance: Some Evidence from the French Industry, Industry and Innovation, 19(7), 607-630.

MAIETTA, O. W. (2015), Determinants of University-Firm R\&D Collaboration and Its Impact on Innovation: A Perspective from a Low-Tech Industry, Research Policy, 44(7), 1341-1359.

MALERBA, F. (2005), Sectoral Systems of Innovation: A Framework for Linking Innovation to the Knowledge Base, Structure and Dynamics of Sectors, Economics of Innovation and New Technology, 14 (1-2), 63-82.

MCCANN, R., ORTEGA-ARGILÈS, R. (2015), Smart Specialization, Regional Growth and Applications to European Union Cohesion Policy, Regional Studies, 49(8), 1291-1302. MCGRANAHAN, D. A., WOJAN, T. R., LAMBER, D. M. (2011), The Rural Growth Trifecta: Outdoor Amenities, Creative Class and Entrepreneurial Context, Journal of Economic Geography, 11(3), 529-557.

MILGROM, P., ROBERTS, J. (1990), The Economics of Modern Manufacturing: Technology, Strategy and Organization, American Economic Review, 80, 511-528.

NALDI, L., NILSSON, P., WESTLUND, H., WIXE, S. (2015), What is Smart Rural Development?, Journal of Rural Studies, 40, 90-101.

NEFFKE, F., HENNING, M., BOSCHMA, R., (2011) How Do Regions Diversify over Time? Industry Relatedness and the Development of New Growth Paths in Regions, Economic Geography, 87(3), 237-265.

PORTER, M. E., VAN DER LINDE, C. (1995), Toward a New Conception of EnvironmentCompetitiveness Relationship, Journal of Economic Perspectives, 9(4), 97-118.

RENNINGS, K. (2000), Redefining Innovation: Eco-Innovation Research and the Contribution from Ecological Economics, Ecological Economics, 32(2), 319-332.

SHEARMUR, R., DOLOREUX, D. (2016), How Open Innovation Processes Vary between Urban and Remote Environments: Slow Innovators, Market-Sourced Information and Frequency of Interaction, Entrepreneurship $\mathcal{G}$ Regional Development, 28(5-6), 1-21.

SHUTJENS, V., STAM, E. (2003), The Evolution and Nature of Young Firm Networks: A Longitudinal Perspective, Small Business Economics, 21, 115-134.

STEINER, M., MOSSBÖCK, J. (2014), How 'Smart' are Rural Areas? A Case Study Approach, RSA Winter Conference, November 27-28, London, UK.

TEMRI, L. (2011), Innovations technologiques environnementales dans les petites entreprises: proposition d'un modèle d'analyse, Innovations, 34, 11-36.

TORRE, A., WALlET, F., (2015), Towards New Paths for Regional and Territorial Development in Rural Areas, European Planning Studies, 23(4), 650-677.

TRIGUERO, A., MORENO-MONDÉJAR, L., DAVIA, M. A. (2013), Drivers of Different Types of Eco-Innovation in European SMEs, Ecological Economics, 92, 25-33.

pre-published - Journal of Innovation Economics \& Management 2017 XXVII 
WAGNER, M., LLERENA, P. (2011), Eco-Innovation through Integration, Regulation and Cooperation: Comparative Insights from Case Studies in Three Manufacturing Sectors, Industry and Innovation, 18(8), 747-764.

WASSERMAN, S., FAUST, K. (1995), Social Network Analysis: Methods and Applications, New York Cambridge, Cambridge University Press. 